\author{
Kuprina $\mathbf{N}$. \\ Ph.D., Associate Professor \\ Department of Accounting and Auditing \\ E-mail:k.natali_@ukr.net \\ ORCID ID: 0000-0003-4645-545X
}

\author{
Markova T. \\ Ph.D., Associate Professor \\ Department of Accounting and Auditing \\ E-mail: markova.tetiana17@gmail.com \\ ORCID ID: 0000-0002-9437-2635
}

\author{
The student of the third grade of Economy, Business and Control Faculty Odessa National \\ Odessa National Academy of Food Technologies \\ Kanatna str., 112, Odesa, Ukraine, 65039 \\ E-mail: velichko20012001@gmail.com \\ ORCID ID: 0000-0002-8591-878X
}

\title{
ASPECTS OF FINANCIAL ANALYSIS OF THE COMPANY'S EQUITY IN MODERN CONDITIONS
}

The purpose of the research is to analyze the scientific works on the o study approaches to conducting financial analysis of industrial equity of enterprises in the theoretical and practical aspect, justification of the need to formulate a comprehensive approach for such aanalysis of the equity of the enterprise in the management system.

The analysis of the works of scientists showed that when conducting a financial analysis of an enterprise's equity, it is mainly conducted in the context of the analysis of the financial condition of the enterprise, both in the overall assessment and in absolute and relative terms, which is not complete in the current conditions of managing the enterprise resources and sources of their formation.

The scientific result of the research is the formation of a comprehensive approach to the financial analysis of the equity of an industrial enterprise, which is relevant in the current market conditions of operation of enterprises and covers the analysis of its dynamics, structure, turnover, profitability, risk and its protection. The practical importance of this work is directed to the use of this method of equity analysis as a tool of financial analysis in the modern conditions of management of industrial enterprises to ensure the efficiency of their activities and management.

Key words: capital, equity, financial analysis, integrated approach, industrial enterprise.

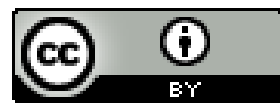

This work is licensed under a Creative Commons Attribution 4.0 International License http://creativecommons.org/licenses/by/4.0/
Statement of the problem and its connection with important scientific and practical tasks. Capital is a basic structural component of the development of any business, and capital, which is focused on long-term economic success at is complex, multidimensional and, therefore, an under-researched economic category, and there are various approaches to defining and structuring it. In particular, the imbalance in the capital structure is one of the important problems of the activity of any business entity and often leads to a decrease in the efficiency of its activity and a decrease in the values of financial and economic indicators. In addition, one of the main causes of the crisis for most Ukrainian business entities is the existence of an uneven capital management system, incorrect definition and calculation of the ratio between equity and attracted capital, ensuring its efficient use and risks. That is why it is very important for an industrial enterprise to develop tools for determining such a balance, to conduct a qualitative analysis of equity capital, to timely and effectively adapt approaches to such assessment in the current conditions of internal and external environment of the enterprise functioning.
The analysis of the latest publications on the problem. The works of scientific and practical direction by Antonyuk O.P., Barabash N.S., Blanka I.O., Vlasyuk N.I., Deeva N.M., Mnyha Ye.V., Polyakova G.B., Tsal-Tsalko Y.S., Sheremeta O.O. and other scholars are devoted to Investigation of aspects of financial analysis, including the equity of the enterprise. However, it should be noted that some aspects of financial equity analysis and the study of the nature of these categories are still debatable and need further investigation and elaboration.

Forming of the aims of the research.The purpose of the research in the article is to analyze and systematize the economic scientific and educational literature on issues of economic essence, composition and classification, aspects of financial analysis of the equity of an industrial enterprise in modern conditions.

The achievement of this goal is conditioned by the following tasks: analysis of approaches to equity structuring; study of aspects of the financial analysis of equity of an enterprise and its carrying out by the materials of the enterprise of food industry of Odessa region; 
forming recommendations on a comprehensive approach to the analysis of the equity of an enterprise in modern conditions. The object of study is the equity of an enterprise, and the subject of the study - theoretical and practical approaches to the formation and conduct of financial analysis of equity in enterprises in modern conditions of their operation. The theoretical and practical basis is the study of domestic and foreign scientific and practical works on this problem, information materials of Internet sites.

To solve the problems of the study, the following methods were used: the method of structural-logical analysis (when forming the structure and logic of article); systematic benchmarking, synthesis and grouping method (to analyze approaches to the classification of capital and equity of the enterprise); method of absolute and relative values, comparative analysis, graphical method (for conducting financial analysis of equity of an industrial enterprise).

Giving an account of the main results and their substantiation. A study of the statistical dynamics of changes in the structure of equity of enterprises by type of economic activity of Ukraine for six years (at the beginning of the year, Fig.1) shows that since 2015 the structure of registered capital, additional capital has changed dramatically and there is uncovered loss, which has a negative tendency to increase [1].

Such changes in the formation of equity of enterprises by type of economic activity of Ukraine were affected by the economic crisis of 2015. Given the low value of retained earnings, there the relevance of effective equity management becomes clear, because it is due to this component is an increase in equity and expansion of economic activity.

Thus, the analysis of the dynamics and structure of the balance sheet of enterprises by type of economic activity of Ukraine for six years (Table 1) shows an increase in the balance sheet currency by $90 \%$ [1].

The asset structure of the balance sheet of enterprises by type of economic activity of Ukraine has a stable ratio of current and non-current assets. Note that the share of non-current assets is $42-49 \%$, and non-current assets $-50-57 \%$.

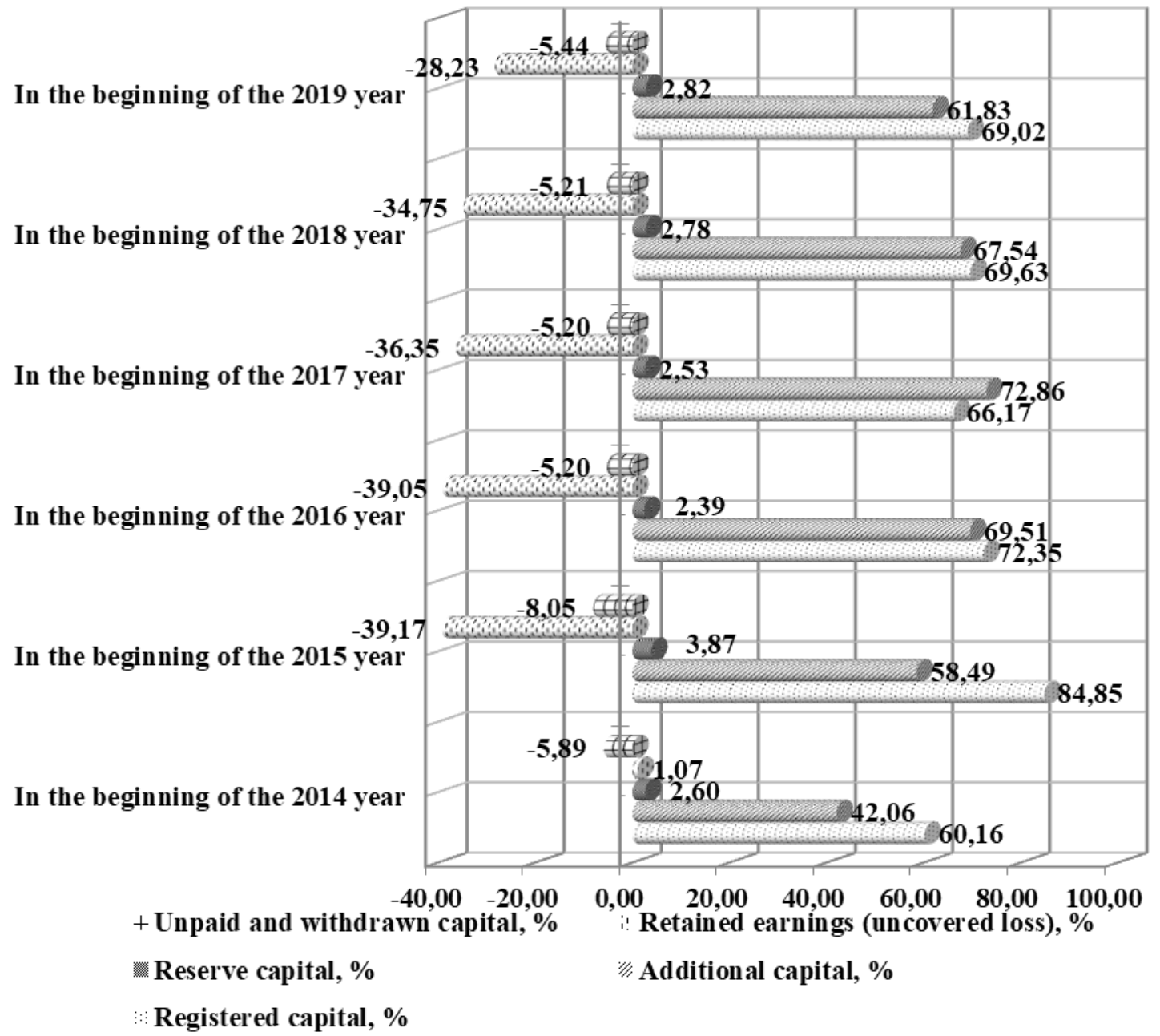

Fig. 1. Dynamics of change in the structure of equity of enterprises by type of economic activity of Ukraine for 2014-2019*

*compiled by author based on sources [12] 
Table 1

Dynamics and structure of the balance of enterprises by types of economic activity of Ukraine for 2013-2019*

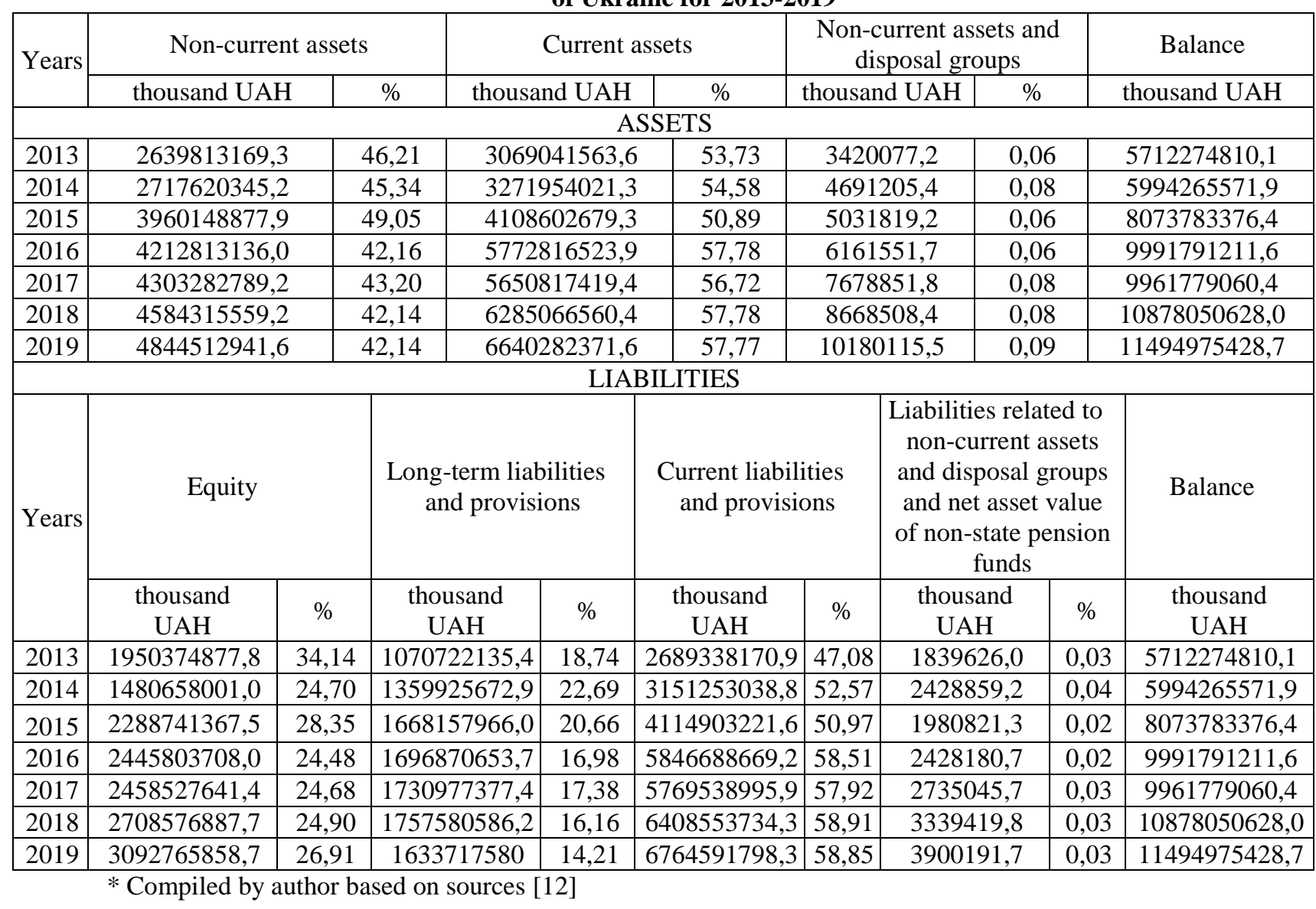

Analysis of the structure of liabilities of the balance sheet of enterprises by type of economic activity of Ukraine shows that most of the current liabilities and provisions are from $47 \%$ to $59 \%$. Equity ranks second in the structure of the balance sheet and its share ranges from $24 \%$ to $34 \%$. Long-term liabilities and provisions cover up to $22 \%$ of the sources of assets of Ukrainian enterprises [1].

The study showed that such proportions could not but affect the efficiency of enterprise equity management by type of economic activity of Ukraine. And each owner has a task to develop and improve the management system of equity, to find leverage to «increase (decrease) equity, the order of formation of reserve (insurance) capital, the order of formation and use of additional capital, methods of reinvestment in corporate rights, taxation operations that involve an increase (decrease) in registered capital, etc. [2], as the coefficient of financial independence ranges from $24.48 \%$ to $34.14 \%$, while the regulatory value of this figure must be more than $50 \%$ [1].

According to the experience of domestic enterprises, it is an effective system of effective equity management that protects interests, minimizes risks and demonstrates the effect of the use of invested funds is a prerequisite for those enterprises that are interested and preferred by investors [2].

We will carry out the analysis of the own capital of the enterprise with the help of the data of the enterprises of the food industry of Odessa region both unprofitable CJSC «Odesakonditer» (Closed Joint-Stock Company «Odesakonditer»), and profitable - LLC «Druzhba SVK» (Druzhba Silskogospodasky Kooperativ, Limited Liability Company).

To analyze the composition, structure and dynamics of the company's equity and its profitability, consider the data of tables 2-4, according to the form number 1 «Balance sheet (Statement of financial position)» $[3,4]$.

Table 2-3 shows that the equity of the enterprise in 2018 compared to 2017 decreased by 7044 thousand UAH. or $73.66 \%$. This was due to an increase in the uncovered loss of the enterprise by UAH 7,044 thousand. or $10.0 \%$, which is a negative trend. In 2019, compared to 2018, equity continued to decline and thus decreased by UAH 11,408 thousand during the period. or $452.88 \%$. The reason for this was the increase in uncovered loss by UAH 11,408 thousand. (or by $14.71 \%$ ). 
Table 2

Analysis of the composition, structure and dynamics of equity enterprises (CJSC «Odesakonditer»)

\begin{tabular}{|c|c|c|c|c|c|}
\hline \multirow{3}{*}{ Indeces } & \multirow{3}{*}{$\begin{array}{l}\text { Code } \\
\text { line }\end{array}$} & \multicolumn{4}{|c|}{ Deviation } \\
\hline & & \multicolumn{2}{|c|}{2018 from 2017} & \multicolumn{2}{|c|}{2019 from 2018} \\
\hline & & abs. & $\%$ & abs. & $\%$ \\
\hline $\begin{array}{l}\text { Total equity, UAH thousand, } \\
\text { including: }\end{array}$ & 1495 & -7044 & $-73,66$ & -11408 & $-452,88$ \\
\hline \multirow{2}{*}{$\begin{array}{l}\text { 1. Registered (share) capital, } \\
\text { thousand UAH. } \\
\text { - in \% to equity }\end{array}$} & \multirow[t]{2}{*}{1400} & - & - & - & - \\
\hline & & 318,53 & $\mathrm{x}$ & $-554,97$ & $\mathrm{x}$ \\
\hline \multirow{2}{*}{$\begin{array}{l}\text { 2. Capital in revaluation, thousand UAH. } \\
\text { - in } \% \text { to equity }\end{array}$} & \multirow[t]{2}{*}{1405} & - & - & - & - \\
\hline & & - & $\mathrm{x}$ & - & $\mathrm{x}$ \\
\hline \multirow{2}{*}{$\begin{array}{l}\text { 3. Additional capital, thousand UAH. } \\
\text { - in } \% \text { to equity }\end{array}$} & 1410 & - & - & - & - \\
\hline & & 1839,76 & $\mathrm{x}$ & $-3205,46$ & $\mathrm{x}$ \\
\hline \multirow{2}{*}{$\begin{array}{l}\text { 4. Reserve capital, thousand UAH. } \\
\text { - in\% to equity }\end{array}$} & 1415 & - & - & - & - \\
\hline & & 182,45 & $\mathrm{x}$ & $-317,87$ & $\mathrm{x}$ \\
\hline \multirow{2}{*}{$\begin{array}{l}\text { 5. Retained earnings } \\
\text { (uncovered loss), thousand UAH. } \\
\text { - in\% to equity }\end{array}$} & \multirow[t]{2}{*}{1420} & -7044 & 10,0 & -11408 & $-14,71$ \\
\hline & & $-2340,73$ & $\mathrm{x}$ & 4078,30 & $\mathrm{x}$ \\
\hline \multirow{2}{*}{$\begin{array}{l}\text { 6. Unpaid capital, thousand UAH. } \\
\text { - in\% to equity }\end{array}$} & 1425 & - & - & - & - \\
\hline & & - & $\mathrm{x}$ & - & $\mathrm{x}$ \\
\hline \multirow{2}{*}{$\begin{array}{l}\text { 7. Capital withdrawn, thousand UAH. } \\
\text { - in } \% \text { to equity }\end{array}$} & \multirow[t]{2}{*}{1430} & - & - & - & - \\
\hline & & - & - & - & - \\
\hline
\end{tabular}

* Calculated by the authors on the basis of the financial statements

** In the beginning of the year

Table 3

Analysis of the composition of equity enterprises (CJSC «Odesakonditer»)****

\begin{tabular}{|c|c|c|c|c|c|c|c|c|c|}
\hline \multirow[b]{2}{*}{ Indicators } & \multirow[b]{2}{*}{$\begin{array}{l}\text { Line } \\
\text { code }\end{array}$} & \multicolumn{2}{|c|}{$2017 * *$} & \multicolumn{2}{|c|}{$2018 * *$} & \multicolumn{2}{|c|}{ 2019** } & \multicolumn{2}{|c|}{ Deviation } \\
\hline & & $\begin{array}{c}\text { UAH } \\
\text { thousand }\end{array}$ & $\%$ & $\begin{array}{c}\text { UAH } \\
\text { thousand }\end{array}$ & $\%$ & $\begin{array}{c}\text { UAH } \\
\text { thousand }\end{array}$ & $\%$ & $\begin{array}{l}2018 \\
\text { from } \\
2017 \\
\end{array}$ & \begin{tabular}{|c|}
2019 \\
from \\
2018 \\
\end{tabular} \\
\hline $\begin{array}{l}\text { Total equity, } \\
\text { UAH thousand, } \\
\text { including: }\end{array}$ & 1495 & 9563 & 100 & 2519 & 100 & -8889 & 100 & $\mathrm{x}$ & $\mathrm{x}$ \\
\hline $\begin{array}{l}\text { 1. Registered } \\
\text { (share) capital, } \\
\text { thousand UAH }\end{array}$ & 1400 & 10893 & 113,9 & 10893 & 432,43 & 10893 & $-122,54$ & 318,53 & $-554,97$ \\
\hline $\begin{array}{l}\text { 2. Capital in } \\
\text { revaluation, } \\
\text { thousand UAH. }\end{array}$ & 1405 & - & - & - & - & - & - & - & - \\
\hline $\begin{array}{l}\text { 3. Additional } \\
\text { capital, thou- } \\
\text { sand UAH. }\end{array}$ & 1410 & 62916 & 657,9 & 62916 & 2497,66 & 62916 & $-707,80$ & 1839,76 & $-3205,46$ \\
\hline $\begin{array}{l}\text { 4.Reserve capi- } \\
\text { tal, thousand } \\
\text { UAH. }\end{array}$ & 1415 & 6239 & 65,23 & 6239 & 247,68 & 6239 & $-70,19$ & 182,45 & $-317,87$ \\
\hline $\begin{array}{l}\text { 5. Retained } \\
\text { earnings } \\
\text { (uncovered } \\
\text { loss), thousand } \\
\text { UAH. }\end{array}$ & 1420 & -70485 & $-737,03$ & -77529 & $-3077,77$ & -88937 & 10,01 & $-2340,74$ & 4078,30 \\
\hline $\begin{array}{l}\text { 6. Unpaid capi- } \\
\text { tal, thousand } \\
\text { UAH. }\end{array}$ & 1425 & - & - & - & - & - & - & - & - \\
\hline $\begin{array}{l}\text { 7. Capital with- } \\
\text { drawn, thousand } \\
\text { UAH. }\end{array}$ & 1430 & - & - & - & - & - & - & - & - \\
\hline
\end{tabular}

* Calculated by the authors on the basis of the financial statements

** In the beginning of the year 
Table 2-3 shows that the equity of the enterprise in 2018 compared to 2017 decreased by 7044 thousand UAH. or $73.66 \%$. This was due to an increase in the uncovered loss of the enterprise by UAH 7,044 thousand. or $10.0 \%$, which is a negative trend. In 2019 , compared to
2018, equity continued to decline and thus decreased by UAH 11,408 thousand during the period. or $452.88 \%$. The reason for this was the increase in uncovered loss by UAH 11,408 thousand. (or by $14.71 \%$ ).

Table 4

Analysis of Return on Equity (CJSC «Odesakonditer»)*, **

\begin{tabular}{|c|c|c|c|}
\hline \multirow[t]{2}{*}{ Indicators } & \multirow[t]{2}{*}{ Line code } & \multicolumn{2}{|c|}{ Absolute deviation } \\
\hline & & 2018 from 2017 & 2019 from 2018 \\
\hline $\begin{array}{l}\text { 1. Net profit (loss) of the enterprise, } \\
\text { thousand UAH. }\end{array}$ & Ф № 2, p. 2350 (2355) & 8258 & -4364 \\
\hline $\begin{array}{l}\text { 2. Average annual capital of the enterprise, } \\
\text { thousand UAH } * \\
\text { including: }\end{array}$ & Ф № 1, p. 1300 & -7305 & $-3213,5$ \\
\hline - fixed capital $*$ & Ф № 1, p. 1095 & 2680,5 & 3030,5 \\
\hline - working capital * & Ф № 1, p.1195 & $-9985,5$ & -6244 \\
\hline including - own working capital $*$ & Ф № 1, p.1495 - p.1095 & $-13853,5$ & $-12256,5$ \\
\hline 3. Return on equity, $\%$ & & 15,72 & $-15,14$ \\
\hline 4. Return on fixed capital, \% & $\mathrm{x}$ & 108,51 & $-17,23$ \\
\hline 5. Return on working capital, $\%$ & $\mathrm{x}$ & 15,63 & $-33,91$ \\
\hline 6. Return on equity working capital, \% & $\mathrm{x}$ & $\mathrm{x}$ & $\mathrm{x}$ \\
\hline
\end{tabular}

* Calculated by the authors on the basis of the financial statements

** In the beginning of the year

The analysis of the dynamics of profitability of the enterprise capital is carried out according to the forms No. 1 «Balance sheet (Statement of financial position)», forms № 2 «Statement of financial results (Statement of comprehensive income)» [4] and (Table 4) show that that in the reporting year in comparison with the previous indicators of return on capital of the enterprise increased: total capital - by $15.72 \%$ p., due to a decrease in net loss by 8258 thousand UAH. and a decrease in the average annual amount of capital by UAH 730 thousand; fixed capital - by $108.51 \%$ due to the reduction of net loss by UAH 8258 thousand. and from the average annual amount of fixed capital by UAH 2 680,5 thousand; working capital - by $15.63 \%$ due to the reduction of net loss by UAH 8258 thousand. and reduction of the average annual amount of working capital by UAH 9,985.5 thousand; of working capital - by $188.32 \%$ p. at the expense of reducing the net loss by UAH 8258 thousand. and a decrease in the average annual amount of working capital by UAH 13853,5 thousand, these changes relatively positively characterize the activity of the enterprise. If we compare 2019 with 2018, we can conclude that during this period the return on capital of the enterprise decreased: total capital - by $15.14 \%$, due to an increase in net loss by 4364 thousand UAH. and a decrease in the average annual amount of capital by UAH $3,213.5$ thousand; fixed capital - by $17.23 \%$ due to an increase in net loss by 4364 thousand UAH. and an increase in the average annual amount of fixed capital by UAH 3,030.5 thousand; working capital - by $33.91 \%$ due to an increase in net loss by 4364 thousand UAH. and reduction of the average annual amount of working capital by UAH 6,244 thousand owner's equity decreased by UAH $12,256.5$ thousand. Such changes negatively characterize the activities of the enterprise.

The analysis of the financial stability of the enterprise by partial indicators is carried out according to the form number 1 "Balance sheet (statement of financial position)" using the Table $5[3,4]$.

Table 5

Analysis of financial stability of the enterprise by partial figures (CJSC «Odesakonditer»)*,**

\begin{tabular}{|c|c|c|c|c|c|c|}
\hline Indicators & $\begin{array}{c}\text { Algorithm } \\
\text { of calculation } \\
\text { by the line code }\end{array}$ & $2016 * *$ & $2017 * *$ & $2018 * *$ & $2019 * *$ & $\begin{array}{l}\text { Normative } \\
\text { value }\end{array}$ \\
\hline \multirow{2}{*}{$\begin{array}{l}\text { 1. Ratio of antonomy } \\
\left(\mathrm{K}_{\mathrm{ant}}\right)\end{array}$} & 1495 & \multirow{2}{*}{0,5} & \multirow{2}{*}{0,26} & \multirow{2}{*}{0,07} & \multirow{2}{*}{$-0,29$} & \multirow{2}{*}{ more 0,5} \\
\hline & 1900 & & & & & \\
\hline \multirow{2}{*}{$\begin{array}{l}\text { 2. Ratio of relation- } \\
\text { ship of attracted and } \\
\text { own funds }\left(K_{\mathrm{f}}\right)\end{array}$} & $1595+1695++1700$ & \multirow[t]{2}{*}{1,02} & \multirow[t]{2}{*}{2,84} & \multirow[t]{2}{*}{13,15} & \multirow[t]{2}{*}{$-4,41$} & \multirow[t]{2}{*}{ less 1,0} \\
\hline & 1495 & & & & & \\
\hline $\begin{array}{l}\text { 3. Availability of own } \\
\text { current assets }\left(\mathrm{K}_{\mathrm{aca}}\right)\end{array}$ & $\begin{array}{c}1495-1095 \\
\text { or } \\
1495+1595- \\
1095\end{array}$ & 14763 & 1488 & -12944 & -23025 & $\begin{array}{l}\underset{\text { tion }}{\operatorname{magnifica}} \\
\text { ton }\end{array}$ \\
\hline
\end{tabular}




\begin{tabular}{|c|c|c|c|c|c|c|}
\hline \multicolumn{7}{|c|}{ Continue of table 5} \\
\hline Indicators & $\begin{array}{c}\text { Algorithm } \\
\text { of calculation } \\
\text { by the line code }\end{array}$ & $2016 * *$ & $2017 * *$ & 2018 ** & $2019 * *$ & $\begin{array}{l}\text { Normative } \\
\text { value }\end{array}$ \\
\hline \multirow{2}{*}{$\begin{array}{l}\text { 4. Equity maneuver- } \\
\text { ability factor }\left(\kappa_{\operatorname{man}}\right)\end{array}$} & $1495-1095$ & \multirow{2}{*}{0,6} & \multirow{2}{*}{0,16} & \multirow{2}{*}{$-5,13$} & \multirow{2}{*}{2,59} & \multirow{2}{*}{$0,4 \ldots 0,6$} \\
\hline & 1495 & & & & & \\
\hline \multirow{2}{*}{$\begin{array}{l}\text { 5. Security ratio of } \\
\text { working capital with } \\
\text { own current assets } \\
(\mathrm{Ks})\end{array}$} & $1495-1095$ & \multirow[b]{2}{*}{0,37} & \multirow[b]{2}{*}{0,05} & \multirow[b]{2}{*}{$-0,64$} & \multirow[b]{2}{*}{$-1,42$} & \multirow[b]{2}{*}{0,1} \\
\hline & $1195+1200$ & & & & & \\
\hline
\end{tabular}

* Calculated by the authors on the basis of the financial statements

** In the beginning of the year

Table 5 shows that the coefficient of autonomy during each of the studied periods, 2016-2019, is not within the norm, which indicates the instability and financial dependence of the company on external creditors.

The ratio of borrowed and own funds is also not within the norm and shows that at the beginning of 2016 the company by $1 \mathrm{UAH}$. equity attracted UAH 1.02. borrowed funds, in 2017 - UAH 2.84, in 2018 - already UAH 13.15. and in 2019 this figure reached a negative value of $-4.41 \mathrm{UAH}$. Such changes in the ratio negatively characterize the activities of the enterprise.

Table 6

Analysis of enterprise equity (CJSC «Odesakonditer»)*, **

\begin{tabular}{|c|c|c|}
\hline \multirow{2}{*}{ Indicators } & \multicolumn{2}{|c|}{ Deviation } \\
\hline & 2018 from 2017 & 2019 from 2018 \\
\hline 1. Equity protection ratio (Kpr); $(1410+1415) / 1495$ & 20,22 & $-35,23$ \\
\hline 2. Equity risk ratio (Krr); (1495-1410-1415) / (1410+1415) & $-0,04$ & $-0,17$ \\
\hline 3. Registered Capital Protection Ratio (Krcpr); 1415/1495 & 1,83 & $-3,18$ \\
\hline $\begin{array}{l}\text { 4. The coefficient of development of the enterprise (Kde); } \\
(1415+1420-(1415+1420)) / 2350\end{array}$ & $\mathrm{x}$ & $\mathrm{x}$ \\
\hline $\begin{array}{l}\text { 5. Return on equity }(\mathrm{Kre}) \text {; } \\
(2350 \text { or } 2355) /\left(0,5 \times\left(1495+1495^{* * *}\right)\right) \times 100 \%\end{array}$ & $-0,28 * *$ & $4,75^{* *}$ \\
\hline 6. Equity turnover (Ket); 2000/(0,5× $(1495+1495 * * *))$ & 0,56 & $-3,74$ \\
\hline
\end{tabular}

* loss-making activity of the enterprise

** calculated by the authors on the basis of the financial statements

*** to previous year

**** in the beginning of the year

As the calculation showed (Table 6) in 2018, compared to 2017 , the company's equity protection ratio increased by 20.22 , due to a decrease in equity by almost 4 times, which is negative. The equity risk ratio tends to decrease due to an increase in the uncovered loss of the enterprise. The protection ratio of the registered capital increased by UAH 1.83 of reserve capital for 1 UAH. equity, which is negative. The coefficient of development of the enterprise for the period 2017-2018. and return on equity have a negative value and due to unprofitable activities of the company has no path of development and close to bankruptcy. The turnover of equity ranges from 2.19 to 2.75 , but with a reduction in net income and equity of the enterprise. If you compare the results of 2019 with 2018, you can see that the company has reduced the ratio of equity protection by 35.23 , due to the decrease in equity, which is negative. The equity risk ratio tends to decrease due to an increase in the uncovered loss of the enterprise. The protection ratio of the registered capital decreased by UAH 3.18. reserve capital for 1 UAH. Equity, which is negative. The coefficient of enterprise development for the period 2018-
2019. And return on equity are negative due to unprofitable activities of the enterprise. The turnover of equity ranges from 2.75 to -0.99 with a reduction in net income and equity of the enterprise.

Table 5, Fig. 3 shows that the coefficient of autonomy during the period under study is not within the norm, which indicates the instability and financial dependence of the enterprise on external creditors.

The ratio of attracted and own funds is also outside the normal range and shows that the enterprise at the beginning of the previous year attracted UAH 1.02. loans, by $1 \mathrm{UAH}$. equity at the end of the previous year UAH 2.84, at the end of the reporting year - already UAH 13.15; the value of this indicator increases to 13.15 , which negatively characterizes the activity of the enterprise.

The enterprise has its own working capital in the previous year, the value of which decreases and is negative at the end of the reporting year, which caused a decrease in the value of the maneuverability of equity capital at the end of the reporting year. 


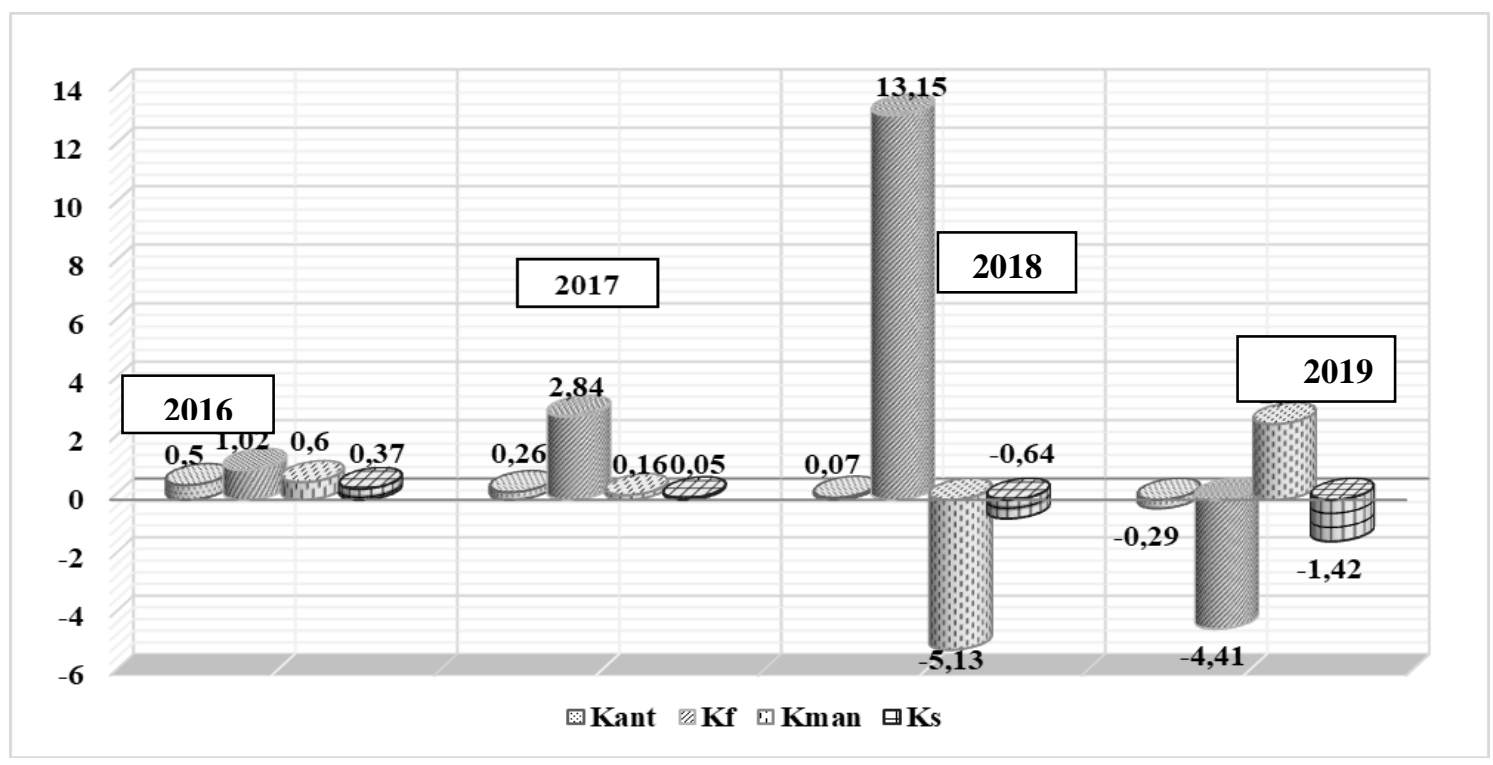

Fig. 3 Analysis of financial stability of the enterprise by partial figures (CJSC «Odesakonditer»)*

* calculated by the authors on the basis of the financial statements

The value of the working capital provision ratio with own working capital has an unstable value during the previous year and a negative value in the reporting one. Thus, the analysis of indicators of financial stability of the enterprise allows to conclude that ineffective investment of funds in the activity of the enterprise and financial instability of functioning of the enterprise in the market tares place.

However, traditional financial analysis needs to be supplemented with equity indicators, which allow to systematize information about the security and efficiency of using the equity of an industrial enterprise in its work and includes separate indicators of business activity, profitability. Finding values within the norm is important for shareholders of the company [5].

Yes, the Equity Protection Ratio (Kpr) is the ratio of the amount of additional and reserve capital to the amount of equity. That is, the formula has the following form $[5,8]$ :

\section{$K p r=$}

(balance liability line $1410+$ balance liability line 1415)

Equity Risk Ratio (Krr) is the ratio of the difference between equity and a dditional and reserve

capital to additional and reserve capital [2]:

$$
K r r=\frac{(\text { balance liability line } 1495-\text { balance liability line } 1410-\text { balance liability line 1415) }}{\text { (balance liability line } 1410+\text { balance liability line 1415) }}
$$

The Registered Capital Protection Ratio (Krcpr)

is defined as the ratio of reserve capital to authorized capital [5,8]:

$$
\text { Krcpr }=\frac{\text { balance liability line } 1415}{\text { balance liability line } 1495}
$$

The coefficient of Development of the reserve capital and retained earnings to the amount of net Enterprise $(\mathrm{Kde})$ is defined as the ratio of the increase in profit $[5,8]$ :

$$
K d e=\frac{\left(\begin{array}{l}
\text { (current year balance liability line } 1415+\text { current year balance liability line } 1420- \\
\text { previous year balance liability line } 1415+\text { previous year balance liability line } 1420)
\end{array}\right.}{\text { line } 2350 \text { of the income statement }}
$$

Return on Quit y (Kre) means the ratio of net income to the average annual amount of equity of an enterprise $[5,8]$ :

line 2350/2355 of the income statement 
Equity turnover (Ket) is the ratio of net income from sales to the average annual amount of equity $[5,8]$ :

\begin{tabular}{|c|c|}
\hline & line 2000 of the income statement \\
\hline Ket $=$ & $\begin{array}{c}(0,5 \times \text { (balance liability line } 1495 \text { in the current year }+ \text { balance liability line } 1495 \text { in } \\
\text { the previous year })\end{array}$ \\
\hline
\end{tabular}

Equity gains (EG) are defined as the difference

between the amount of equity in the current year and the previous year $[5,8]$ :

\section{$E G=\quad$ balance liability line 1495 in the current year + balance liability line 1495 in the previous year}

According to the income approach, the cost of equity equals the ratio of net income to the average annual amount of equity, that is, in fact, equal to the value of the return on equity.

Thus, these indicators allow to obtain the following information about the status, risks and protection of equity of an industrial enterprise [5,8]:

1. Equity Protection Ratio: Demonstrates a portion of equity that performs a hedging function in an enterprise. High value indicates a large reserve fund and additional invested capital, which can be used in the event of unforeseen processes in the enterprise and deterioration of the type of financial stability.

2. Equity risk ratio: the value of the indicator is an indication of the level of risk of the company losing the amount of its statutory capital and accumulated retained earnings. In the event of deviation from the normative value, the confidence in the enterprise itself decreases, because in case of crisis situations there is a risk of non-repayment of the creditors' funds. The normative value is 5 and above. In case of deviation, it is advisable to work towards increasing the statutory capital of the enterprise.

3. Ratio of share capital protection: the ratio indicates the security-status of the statutory capital in the event of difficult unforeseen situations in the enterprise. If the value is low, such as zero, then this is a direct violation of the law. According to the current legislation, the coefficient must be at least 0.15 . If the figure is lower, it is recommended that in the following years, in accordance with the legislation they should, increase the reserve fund by $5 \%$ every year.

4. Self-financing rate of development of an enterprise: means the ability of an enterprise to develop at the expense of carrying out effective activity, which generates considerable profit. The low value of the indicator indicates that most of the profits of the company were taken out of circulation, in particular for payment of dividends to shareholders.

5. Return on equity: allows you to determine the effectiveness of the equity of the company, that is, funds belonging to shareholders. Usually, a high value is a positive indicator. In turn, low value indicates inefficient movement of capital in the enterprise, which leads to a decrease in its value. The upward trend has been a positive trend for several years.

6. Equity turnover: Indicates how many goods and services the enterprise has been able to produce to provide clients with equity investment in this year for each hryvnia. The constant increase in the use of equity is a positive trend and reflects its growth. Thus, increasing the amount of equity is one of the key goals of any business enterprise, so a significant increase in equity may indicate effective management, sound financial, commercial, competitive, industrial policies and more.

7. Equity Costs According to the Income Approach: The profit-and-loss approach to capital appreciation assumes that the fee for using it is the amount of profit received by the enterprise, but in fact the shareholder-owned equity value has increased by that amount. If the cost of equity is high, then it is advisable for the company to attract alternative sources of funds borrowing ones.

To effectively manage equity, businesses recommend that it should be analyzed for the following relative indicators [5,8], using equity indicators (Table 6).

As the calculation showed in 2018, compared to 2017 , the company's equity protection ratio increased by 20.22 , due to a decrease in equity by almost 4 times, which is negative. The equity risk ratio tends to decrease due to an increase in the uncovered loss of the enterprise. The protection ratio of the registered capital increased by UAH 1.83 of reserve capital for $1 \mathrm{UAH}$. equity, which is negative. The coefficient of development of the enterprise for the period 2017-2018. and return on equity have a negative value and due to unprofitable activities of the company has no path of development and close to bankruptcy. The turnover of equity ranges from 2.19 to 2.75 , but with a reduction in net income and equity of the enterprise. If you compare the results of 2019 with 2018 , you can see that the company has reduced the ratio of equity protection by 35.23 , due to the decrease in equity, which is negative. The equity risk ratio tends to decrease due to an increase in the uncovered loss of the enterprise. The protection ratio of the registered capital decreased by $\mathrm{UAH}$ 3.18. reserve capital for $1 \mathrm{UAH}$. equity, which is negative. The coefficient of enterprise development for the period 2018-2019. and return on equity are negative due to unprofitable activities of the enterprise. The turnover of equity ranges from 2.75 to -0.99 with a reduction in net income and equity of the enterprise.

Thus, on the example of CJSC «Odesakonditer» we considered the activities of a loss-making enterprise. Now we have the opportunity to analyze and compare the same calculated indicators for the company LLC «Druzhba SVK», which is demonstrating profitable activities.

To analyze the composition, structure and dynamics of equity of the enterprise and its profitability, we use the data of tables 7-9 according to the form № 1 «Balance Sheet (Statement of financial position)» [6,7]. 
Analysis of the composition, structure and dynamics of equity enterprises (LLC «Druzhba SVK»)*,**

\begin{tabular}{|c|c|c|c|c|c|c|c|}
\hline \multirow{3}{*}{ Indeces } & \multirow{3}{*}{$\begin{array}{l}\text { Code } \\
\text { line }\end{array}$} & \multicolumn{6}{|c|}{ Deviation } \\
\hline & & \multicolumn{2}{|c|}{2017 from 2016} & \multicolumn{2}{|c|}{2018 from 2017} & \multicolumn{2}{|c|}{2019 from 2018} \\
\hline & & abs. & $\%$ & abs. & $\%$ & abs. & $\%$ \\
\hline $\begin{array}{l}\text { Total equity, UAH thousand, } \\
\text { including: }\end{array}$ & 1495 & 29156 & 20,29 & 20946 & 12,12 & -10371 & $-5,35$ \\
\hline \multirow{2}{*}{$\begin{array}{l}\text { 1. Registered (share) capital, thousand } \\
\text { UAH. } \\
\text { - in } \% \text { to equity }\end{array}$} & \multirow[t]{2}{*}{1400} & - & - & - & - & -19528 & $-98,56$ \\
\hline & & $-2,33$ & $\mathrm{x}$ & $-1,24$ & $\mathrm{x}$ & $-10,06$ & $\mathrm{x}$ \\
\hline \multirow{2}{*}{$\begin{array}{l}\text { 2. Capital in revaluation, thousand UAH } \\
\text { - in } \% \text { to equity }\end{array}$} & \multirow[t]{2}{*}{1405} & - & - & - & - & -336 & -100 \\
\hline & & $-0,04$ & $\mathrm{x}$ & $-0,02$ & $\mathrm{x}$ & $-0,17$ & -100 \\
\hline \multirow{2}{*}{$\begin{array}{l}\text { 3. Additional capital, thousand UAH. } \\
\text { - in\% to equity }\end{array}$} & 1410 & - & - & - & - & -61 & - \\
\hline & & - & $\mathrm{x}$ & $-0,01$ & $\mathrm{x}$ & $-0,03$ & $\mathrm{x}$ \\
\hline \multirow{2}{*}{$\begin{array}{l}\text { 4. Reserve capital, thousand UAH. } \\
\text { - in \% to equity }\end{array}$} & 1415 & -2264 & $-4,83$ & -7877 & $-17,65$ & 18204 & 49,54 \\
\hline & & $-6,82$ & $\mathrm{x}$ & $-6,85$ & $\mathrm{x}$ & 11,00 & $\mathrm{x}$ \\
\hline \multirow{2}{*}{$\begin{array}{l}\text { 5. Retained earnings (uncovered loss), } \\
\text { thousand UAH. } \\
\text { - in } \% \text { to equity }\end{array}$} & \multirow[t]{2}{*}{1420} & 31460 & 41,08 & 28783 & 26,64 & -8650 & $-6,32$ \\
\hline & & 9,19 & $\mathrm{x}$ & 8,12 & $\mathrm{x}$ & $-0,74$ & $\mathrm{x}$ \\
\hline \multirow{2}{*}{$\begin{array}{l}\text { 6. Unpaid capital, thousand UAH. } \\
\text { - in\% to equity }\end{array}$} & 1425 & - & - & - & - & - & - \\
\hline & & - & - & - & $\mathrm{x}$ & - & $\mathrm{x}$ \\
\hline \multirow{2}{*}{$\begin{array}{l}\text { 7. Capital withdrawn, thousand UAH. } \\
\text { - in } \% \text { to equity }\end{array}$} & \multirow[t]{2}{*}{1430} & - & - & - & - & - & - \\
\hline & & - & - & - & - & - & \\
\hline
\end{tabular}

* Calculated by the authors on the basis of the financial statements

** In the end of the year

Table 7 shows that the company's equity in 2017 compared to 2016 increased by 29156 thousand UAH. or by $20.29 \%$. This was due to an increase in retained earnings of the company by 31460 thousand UAH. or $41.08 \%$, which is a positive trend. In 2018, the upward trend continues: equity increased by UAH 20,946 thousand. or $12.12 \%$ due to the increase in retained earnings by UAH 28,783 thousand. or $26.64 \%$. In 2019 , equity decreased by UAH 10,371 thousand. or $5.35 \%$. The reason for this is the decrease in retained earnings by UAH $8,650,000$. (or $6.32 \%$ ), share capital by UAH 19,528 thousand. (or $98.56 \%$ ), capital in revaluations and additional capital by $100 \%$. At the same time, the reserve capital increased by UAH 18,204 thousand (49.54\%).

Table 8

Analysis of Return on Equity (LLC «Druzhba SVK»)*, **

\begin{tabular}{|c|c|c|c|c|}
\hline \multirow[b]{2}{*}{ Indicators } & \multirow[b]{2}{*}{ Line code } & \multicolumn{3}{|c|}{ Absolute deviation } \\
\hline & & $\begin{array}{l}2017 \text { from } \\
2016\end{array}$ & $\begin{array}{l}2018 \text { from } \\
2017\end{array}$ & $\begin{array}{l}2019 \text { from } \\
2018\end{array}$ \\
\hline $\begin{array}{l}\text { 1. Net profit (loss) of the enterprise, thou- } \\
\text { sand UAH. }\end{array}$ & $\begin{array}{c}\Phi \text { № } 2 \\
\text { p. } 2350(2355) \\
\end{array}$ & 11990 & -3361 & -27737 \\
\hline $\begin{array}{l}\text { 2. Average annual capital of the enterprise, } \\
\text { thousand } \mathrm{UAH} * \\
\text { including: }\end{array}$ & $\begin{array}{l}\text { Ф № } 1 \\
\text { p. } 1300\end{array}$ & 29131 & 29944 & 20217 \\
\hline - fixed capital $*$ & $\Phi$ № 1, p. 1095 & 7096,5 & 16345,5 & -11350 \\
\hline - working capital $*$ & $\begin{array}{l}\Phi \text { № } 1 \\
\text { p.1195 }\end{array}$ & 22034,5 & 13598,5 & 8867 \\
\hline including - own working capital $*$ & $\begin{array}{c}\text { Ф № } 1 \\
\text { p.1495 - p.1095 }\end{array}$ & 21936,5 & 8705,5 & $-6062,5$ \\
\hline 3. Return on equity, $\%$ & & 3,26 & $-5,94$ & $-15,16$ \\
\hline 4. Return on fixed capital, $\%$ & $\mathrm{x}$ & 13,85 & $-25,15$ & $-43,58$ \\
\hline 5. Return on working capital, $\%$ & $\mathrm{x}$ & 3,93 & $-7,05$ & $-23,23$ \\
\hline
\end{tabular}

* Calculated by the authors on the basis of the financial statements

** In the end of the year

The analysis of the dynamics of return on capital of the enterprise (Table 8) shows that in 2016 and 2017 indices of the return on capital of the enterprise increased respectively: total capital - by $3.26 \%$, due to an increase in net profit by 11990 thousand UAH. and an increase in the average annual amount of capital by UAH 29,131 thousand; of fixed capital - by $13.85 \%$ due to an increase in net profit by UAH 11,990 thousand. And from the 
average annual amount of fixed capital by UAH 7096.5 thousand; working capital - by $3.93 \%$ due to an increase in net profit by UAH 11,990 thousand. and an increase in the average annual amount of working capital by UAH $22,034.5$ thousand; of own entity - by $3.87 \%$ due to an increase in net profit by UAH 11,990 thousand. and an increase in the average annual amount of own entity by UAH 21,936.5 thousand, these changes positively characterize the activities of the enterprise for the period. But in 2018 and 2019 there is a tendency to reduce certain indicators of profitability. Thus, in 2018 compared to 2017, indices of the return on capital of the enterprise decreased: total capital - by $5.94 \%$, due to a decrease in net profit by 3361 thousand $\mathrm{UAH}$, but with an increase in the average annual amount of capital by 29944 thousand UAH. ; fixed capital - by $25.15 \%$ due to a decrease in net income by 3361 thousand UAH. and an increase in the average annual amount of fixed capital by UAH 16,345.5 thousand; working capital - by $7.05 \%$ due to a decrease in net profit by 3361 thousand UAH. and an increase in the average annual amount of working capital by UAH $13,598.5$ thousand; own entity - by $5.87 \%$ due to a decrease in net profit by 3361 thousand UAH. and increase of own entity by UAH 8705.5 thousand. In 2019, compared to 2018, indices of the company's return on capital decreased: total capital - by $15.16 \%$, due to a decrease in net profit by UAH 27,737 thousand, but with an increase in the average annual amount of capital by UAH 20,217 thousand; of fixed capital - by $43.58 \%$ due to a decrease in net income by UAH 27,737 thousand. and reduction of the average annual amount of fixed capital by UAH 11,350 thousand; own entity - by $23.23 \%$ due to a decrease in net profit by UAH 27,737 thousand. and an increase in the average annual amount of working capital by UAH $8,867,000$; of own entity - by $23.39 \%$ due to a decrease in net profit by UAH 27,737 thousand and reduction of own entity by UAH 6062.5 thousand.

Table 9

Analysis of financial stability of the enterprise by partial figures (LLC «Druzhba SVK»)*,**

\begin{tabular}{|c|c|c|c|c|c|c|}
\hline Indicators & $\begin{array}{c}\text { Algorithm } \\
\text { of calculation } \\
\text { by the line code }\end{array}$ & $2016 * *$ & $2017 * *$ & $2018 * *$ & $2019 * *$ & $\begin{array}{l}\text { Normative } \\
\text { value }\end{array}$ \\
\hline \multirow[b]{2}{*}{ 1. Ratio of antonomy $\left(\mathrm{K}_{\mathrm{ant}}\right)$} & 1495 & \multirow{2}{*}{0,98} & \multirow{2}{*}{0,99} & \multirow{2}{*}{0,94} & \multirow{2}{*}{0,86} & \multirow{2}{*}{ more 0,5} \\
\hline & 1900 & & & & & \\
\hline \multirow{2}{*}{$\begin{array}{l}\text { 2. Ratio of relationship of attracted } \\
\text { and own funds }\left(\mathrm{K}_{\mathrm{f}}\right)\end{array}$} & $1595+1695++1700$ & \multirow{2}{*}{0,02} & \multirow{2}{*}{0,01} & \multirow{2}{*}{0,06} & \multirow{2}{*}{0,17} & \multirow{2}{*}{ less 1,0} \\
\hline & 1495 & & & & & \\
\hline $\begin{array}{l}\text { 3. Availability of own current } \\
\operatorname{assets}\left(K_{\text {aca }}\right)\end{array}$ & $\begin{array}{c}1495-1095 \\
\text { or } \\
1495+1595-1095\end{array}$ & 96867 & 117542 & 124489 & 133091 & magnification \\
\hline \multirow{2}{*}{$\begin{array}{l}\text { 4. Equity maneuverability factor } \\
\left(\mathrm{K}_{\operatorname{man})}\right.\end{array}$} & $1495-1095$ & \multirow{2}{*}{0,67} & \multirow{2}{*}{0,68} & \multirow{2}{*}{0,59} & \multirow{2}{*}{0,57} & \multirow{2}{*}{$0,4 \ldots 0,6$} \\
\hline & 1495 & & & & & \\
\hline $\begin{array}{l}\text { 5. Security ratio of working capital } \\
\text { with own current assets (Ks) }\end{array}$ & $1495-1095$ & 0,97 & 0,99 & 0,90 & 0,77 & 0,1 \\
\hline
\end{tabular}

* Calculated by the authors on the basis of the financial statements

** In the end of the year

The ratio of borrowed and own funds (Table 9) is also within the norm and shows that at the beginning of 2016 the company by 1 UAH. equity attracted UAH 0.02 . borrowed funds, in 2017 - UAH 0.01, in 2018 - UAH 0.06. and in 2019 this figure reaches UAH 0.17. Such changes in the ratio positively characterize the activities of the enterprise.

The company has its own working capital for all years of the period, the amount of which increases with each passing year. The coefficient of maneuverability of equity is within the established limits, but with each passing year there is a decrease. The value of the ratio of working capital to own entity has a stable value during 2016-2018, but in 2019 compared to 2018 decreases by 0.13 . Thus, the analysis of indicators of financial stability of the enterprise allows to draw a conclusion about effective investment of money in activity of the enterprise and financial stability of functioning of the enterprise in the market.

Table 10

Analysis of enterprise equity (LLC «Druzhba SVK»)*, **, ***

\begin{tabular}{|l|c|c|c|}
\hline \multicolumn{1}{|c|}{ Indicators } & \multicolumn{3}{|c|}{ Deviation } \\
\cline { 2 - 4 } & $\begin{array}{c}\mathbf{2 0 1 7} \text { from } \\
\mathbf{2 0 1 6}\end{array}$ & $\begin{array}{c}\mathbf{2 0 1 8} \text { from } \\
\mathbf{2 0 1 7}\end{array}$ & $\begin{array}{c}\mathbf{2 0 1 9} \text { from } \\
\mathbf{2 0 1 8}\end{array}$ \\
\hline 1. Equity protection ratio (Kpr); (1410+1415)/1495 & $-0,07$ & $-0,07$ & 0,11 \\
\hline 2. Equity risk ratio (Krr); (1495-1410-1415)/(1410+1415) & 0,81 & 1,4 & $-1,93$ \\
\hline 3. Registered Capital Protection Ratio (Krcpr); 1415/1495 & $-0,07$ & $-0,07$ & 0,11 \\
\hline
\end{tabular}


Continue of table 10

\begin{tabular}{|c|c|c|c|}
\hline \multirow[b]{2}{*}{ Indicators } & \multicolumn{3}{|c|}{ Deviation } \\
\hline & $\begin{array}{l}2017 \text { from } \\
2016\end{array}$ & $\begin{array}{l}2018 \text { from } \\
2017\end{array}$ & $\begin{array}{l}2019 \text { from } \\
2018\end{array}$ \\
\hline $\begin{array}{l}\text { 4. The coefficient of development of the enterprise (Kde); } \\
(1415+1420-(1415+1420)) / 2350\end{array}$ & $-0,26$ & $-0,15$ & 0,3 \\
\hline $\begin{array}{l}\text { 5. Return on equity (Kre); } \\
(2350 \text { or } 2355) /(0,5 \times(1495+1495 * *)) \times 100 \%\end{array}$ & 0,03 & $-0,06$ & $-0,15$ \\
\hline 6. Equity turnover $($ Ket $) ; 2000 /\left(0,5 \times\left(1495+1495^{* *}\right)\right)$ & 0,23 & $-0,07$ & $-0,19$ \\
\hline
\end{tabular}

$*$ Calculated by the authors on the basis of the financial statements

** To previous year

$* * *$ Iin the end of the year

From Table 10 we have the opportunity to obtain information on the status, risks and protection of equity of Druzhba SVK LLC:

1. The ratio of equity protection in the period from 2016 to 2018 decreases, but in 2019 there is an increase.

2. The risk ratio of equity according to the norms must be 5 and above. For all of the 4 years only in 2018, it is approaching the value and is 4.27 . For all other years it ranges from 2.06 to 2.87 .

3 . The coefficient of protection of the authorized capital in accordance with current legislation must be at least 0.15 , which we can observe on the example of our company. Since 2018, there has been an annual increase in its level to 0.30, although in 2016-2018 there was a decline from 0.33 to 0.19 .

4. The coefficient of development of the enterprise by self-financing shows unstable values in 2016-2018, when it decreases, but since the end of 2018 there is a tendency to increase it.

5. Return on equity during the period from 2016 to 2017 grew annually, which served as a positive phenomenon. But since 2018, it has fallen sharply, for example, in 2019 by 0.15 . This indicates an inefficient movement of capital in the enterprise, which leads to a decrease in its value.

6 . The indicator of return on equity shows that in 2016-2017 there was a constant increase in the intensity of use of equity, which was a positive trend and reflected its growth. But starting in 2018, its value decreased by 0.07 and 0.19 , respectively.

The definition of a system of effective equity management in a newly created or existing enterprise is a prerequisite and guarantee of stable development of financial and economic activities [10-11], as a result of research of literature sources [10-11], we offer five stages of the system of effective capital management.

Conclusions and prospects of the further investigations. The conducted research allows to make the following conclusions:

1. The sustainable development of domestic enterprises, ensuring their efficiency and competitiveness in modern conditions requires a systematic approach to managing the equity of the enterprise, the formation of an effective management policy, the first stage of which is a qualitative comprehensive financial analysis in the previous period, which was formed and analyzed in this work, namely: analysis of the composition, structure and dynamics of the company's own capital; analysis of financial stability indicators of the enterprise, characterizing the equity of the enterprise and its relation with the attracted funds; analysis of the relative indices of equity: risk ratio of equity; enterprise development; return on equity; equity turnover; increase in equity.

2. The definition of a system of effective equity management in a newly created or existing enterprise is a prerequisite and guarantee of stable development of financial and economic activities. As a result of research of literature sources, we offer five stages of the system of effective capital management: management of the process of equity formation, formation of a system of effective assessment of equity, determining the optimal structure of equity, management of the process of using equity, management of the process of maintaining and increasing equity, which requires further research and development.

\section{References}

1. Kuprina, N., Markova, T., \& Stupnytska, M. (2020). Analysis of the own capital of Ukrainian enterprises and features of its management in the conditions of the new economy of the global market. Food Industry Economics, 12(2), 30-37. doi: 10.15673/fie.v12i2.1737.

2. Blank, I. A. (1999). Osnovyi finansovogo menedzhmenta. Kyiv: Nika-Tsentr.

3.Stupnytska, T.M. (2015). Finansovyi analiz z ohliadu na ymorirnist bankrutstva pidpryiemstva. In V.V. Nemchenko (Ed.), Oblikovo-analitychne zabezpechennia v umovakh upravlinnia finansovo-ekonomichnoiu bezpekoiu pidpryiemstva (pp. 105-112). Odesa: Feniks.

4. Tsal-Tsalko, Yu. S. (2008). Finansovyi analiz. Kyiv: TsUL.

5.Kobyletskyi, V. R. Metodyka rozrakhunku pokaznykiv vlasnoho kapitalu. Retrieved January 8, 2020, from https://www.finalon.com/metodyka-rozrakhunku/92-analiz-vlasnoho-kapitalu-ua 
6. Burkynskyi, B. V., \& Horiachuk, V. F. (2014). Kapitalizatsiia ekonomiky rehioniv Ukrainy. Odesa: IPREED NANU.

7.Sokyrynska, I.H. (2003). Diahnostyka finansovoho zabezpechennia diialnosti pidpryiemstva. Finansy Ukrainy, (1), 88-95. doi: 10.1136/adc.88.2.95-a.

8. Kuprina, N., Markova, T., Volodina, O., \& Stupnytska, M. (2020). Peculiarities of analysis of enterprise's own capital in modern conditions. Food Industry Economics, 12(1), 35-44. doi: 10.15673/fie.v12i1.1667.

9. Mishchuk, Ye. V., \& Mishchenko, V. V. (2015). Osoblyvosti systemy upravlinnia vlasnym kapitalom pidpryiemstva ta shliakhy yii vdoskonalennia. Ahrosvit, (24), 46-49.

10. Kirsanova, T. O., \& Koliada, N. O. (2010). Systema upravlinnia vlasnym kapitalom pidpryiemstva. Visnyk SumDU, (1), 58-63.

11. Silakova, H. V., \& Pietukhova, O. M. (2018). Suchasni pohliady na upravlinnia vlasnym kapitalom pidpryiemstva. Intelekt XXI, 3, 101-105.

12. Vlasnyi kapital pidpryiemstv za vydamy ekonomichnoi diialnosti. Derzhavna sluzhba statystyky Ukrainy. Retrieved January 12, 2021, from http://www.ukrstat.gov.ua

Received 16 January 2021

Approved 30 January 2021 Available in Internet 18.04.21

\section{Купріна H.M.}

кандидат економічних наук, доцент кафедра обліку та аудиту

E-mail:k.natali_@ukr.net

ORCID ID: 0000-0003-4645-545X

\author{
Маркова Т.Д. \\ кандидат економічних наук, доцент \\ кафедра обліку та аудиту \\ E-mail: markova.tetiana17@gmail.com \\ ORCID ID: 0000-0002-9437-2635
}

\author{
Величко О.М. \\ студентка 3 курсу фракультету економіки, бізнесу і контролю \\ Одеська національна академія харчових технологій \\ вул. Канатна 112, м. Одеса, Україна, 65039 \\ E-mail: velichko20012001@gmail.com \\ ORCID ID: 0000-0002-8591-878X
}

\title{
АСПЕКТИ ФІНАНСОВОГО АНАЛІЗУ ВЛАСНОГО КАПІТАЛУ ПІДПРИЄМСТВА В СУЧАСНИХ УМОВАХ
}

Метою дослідження в даній публікації є аналіз наукових праць вчених з вивчення підходів до проведення фрінансового аналізу власного капіталу підприємств в теоретичному і практичному аспекті, обґрунтування необхідності та фрормування комплексного підходу такого аналізу в системі управління ним. Аналіз робіт вчених показав, що при проведенні фінансового аналізу власного капіталу підприємства він, в основному, проводиться в контексті аналізу фінансового стану підприємства як в загальній оцінці, так і в абсолютному і відносному вираженні, що не $є$ повним в сучасних умовах управління ресурсами підприємства і джерелами їх формування. Дослідження підтвердило, що стійкий розвиток вітчизняних підприємств, забезпечення їх ефективності та конкурентоспроможності в сучасних умовах вимагає системного підходу до управління власним капіталом підприємства, формування ефективної політики управління, першим етапом якої є якісний комплексний фінансовий аналіз у попередній період, який був сформований та проаналізований у цій роботі, а саме: аналіз складу, структури та динаміки власного капіталу підприємства; аналіз показників фінансової стійкості, що характеризують власний капітал підприємства та його зв'язок із залученими коштами; аналіз таких важливих відносних показників власного капіталу: коефріцієнту ризику власного капіталу; коєфіцієнту розвитку підприємства; рентабельності власного капіталу; оборотності власного капіталу; приросту власного капіталу. Запропонований комплексний підхід проведення фінансового аналізу власного катпіталу підприємства було розраховано на підставі даних двох підприємств за три роки - ЗАТ «Одесакондитер» та ТОВ «Дружба СВК». В статті проаналізовано структуру вкладення капіталу підприємства в його активи та динаміку зміни структури власного капіталу підприємств за видами економічної діяльності України за 2014-2019 роки.

Науковим результатом дослідження $є$ формування комплексного підходу до проведення фрінансового аналізу власного капіталу підприємства, що $є$ актуальним в сучасних умовах функціонування підприємств. 
Практична значимість даної статті спрямована на використання даного методу аналізу власного капіталу як інструменту фінансового аналізу в сучасних умовах управління підприємствами для забезпечення ефективності їх функціонування та управління.

Ключові слова: капітал, власний капітал, фінансовий аналіз, комплексний підхід, підприємство.

\section{Література}

1. Kuprina N., Markova T., Stupnytska M. Analysis of the own capital of Ukrainian enterprises and features of its management in the conditions of the new economy of the global market // Food Industry Economics. 2020. Vol. 12, Issue 2. P. 30-37. doi: 10.15673/fie.v12i2.1737.

2. Бланк И.А. Основы финансового менеджмента: В 2 т. К.: Ника-Центр, 1999. 512 с.

3. Ступницька Т.М. Фінансовий аналіз з огляду на ймовірність банкрутства підприємства / Обліковоаналітичне забезпечення в умовах управління фінансово-економічною безпекою підприємства: монографія // В.В. Немченко, Ф.А. Трішин, Л.В. Іванченкова, Н.М. Купріна, Г.О. Ткачук та ін. ; за заг. ред. д.е.н., проф. В.В. Немченко. Одеса: Фенікс, 2015. С. 105-112.

4. Цал-Цалко Ю.С. Фінансовий аналіз: підруч. К.: ЦУЛ, 2008. 556 с.

5. Кобилецький В.P. Методика розрахунку показників власного капіталу // Онлайн-журнал «Financial Analysis online». URL: https://www.finalon.com/metodyka-rozrakhunku/92-analiz-vlasnoho-kapitalu-ua (дата звернення: 10.01.2021).

6. Буркинський Б.В., Горячук В.Ф. Капіталізація економіки регіонів України: монографія / Ін-т проблем ринку та екон.-екол. досліджень НАН України. Одеса: ІПРЕЕД НАНУ, 2014. 293 с.

7. Сокиринська І. Г. Діагностика фінансового забезпечення діяльності підприємства // Фінанси України. 2003. №1. C. 88-95.

8. Kuprina N., Markova T., Volodina O., Stupnytska M. Peculiarities of analysis of enterprise's own capital in modern conditions // Food Industry Economics. 2020. Vol. 12, Issue 1. P. 35-44. doi: 10.15673/fie.v12i1.1667.

9. Міщук Є.В., Міщенко В.В. Особливості системи управління власним капіталом підприємства та шляхи ії вдосконалення // Агросвіт. 2015. № 24. С. 46-49.

10. Кірсанова Т.О., Коляда Н.О. Система управління власним капіталом підприємства // Вісник СумДУ. Серія економіка. 2010. № 1. С. 58-63.

11. Сілакова Г.В., Пєтухова О.М. Сучасні погляди на управління власним капіталом підприємства. Інтелект XXI. 2018. № 3. С. 101-105.

12. Власний капітал підприємств за видами економічної діяльності // Державна служба статистики України. URL: http://www.ukrstat.gov.ua (дата звернення 12.01.2021).

Стаття надійшла 16.01.2021

Стаття прийнята до друку 30.01.2021

Доступно в мережі Internet 18.04.2021

Цитування згідно ДСТУ 8302:2015

Kuprina N., Markova T., Velychko O. Aspects of financial analysis of the company's equity in modern conditions // Food Industry Economics. 2021. Vol.13, Issue 1. P. 30-42.

Cite as APA style citation

Kuprina, N., Markova, T., \& Velychko, O. (2021). Aspects of financial analysis of the company's equity in modern conditions. Food Industry Economics, 13(1), 30-42. 